\title{
MODEL KEPEMIMPINAN TRANSFORMATIF DALAM MENGEMBANGKAN POLA KEPEMIMPINAN MADRASAH
}

\author{
Argista Rahmaini, Khanan Auladi, Urip Meilina Kurniawati, Istiningsih \\ rahmainiargista09@gmail.com, khananedogawa@gmail.com, \\ 19204080046@student.uin-suka.ac.id, istiningsih81@gmail.com
}

UIN Sunan Kalijaga Yogyakarta

\begin{tabular}{c|c|c}
\hline \hline Received: & Revised: & Aproved: \\
28/01/2021 & $12 / 06 / 2021$ & $16 / 06 / 2021$ \\
\hline \hline
\end{tabular}

\begin{abstract}
This study aims to determine the transformative leadership model in creating leadership patterns in Madrasah Ibtidaiyah (MI). This study uses a qualitative method with the type of literature study. Data collection techniques with documentation obtained from various sources including books, documents, and national journals related to the transformative leadership model. The results of this study indicate that the transformative leadership model can develop leadership patterns in Madrasah Ibtidaiyah (MI) to be better and sensitive to changes and developments of the times as well as science and technology and able to adapt to current events or future events. The pattern of leadership in madrasas with a transformative leadership model makes a madrasa principal who is a catalyst, innovator, motivator, goal planer, activator, action planer, leader, role model, motivator, action planner, goal planner, leader and liaison, has a vision and is an agent of change, and able to adapt to the times.
\end{abstract}

Keywords: Transformative Leadership Model, Leadership Patterns, Head Of Madrasah

\begin{abstract}
Abstrak
Penelitian ini bertujuan untuk mengetahui model kepemimpinan transformatif dalam menciptakan pola kepemimpinan di Madrasah Ibtidaiyah (MI). Penelitian ini menggunakan metode kualitatif dengan jenis studi kepustakaan. Teknik pengumpulan data dengan dokumentasi yang diperoleh dari berbagai sumber antara lain buku, dokumen, dan jurnal nasional yang berkaitan dengan model kepemimpinan transformatif. Hasil penelitian ini menunjukkan bahwa model kepemimpinan transformatif dapat mengembangkan pola kepemimpinan di Madrasah Ibtidaiyah (MI) menjadi lebih baik dan peka terhadap
\end{abstract}


perubahan dan perkembangan zaman serta ilmu pengetahuan dan teknologi serta mampu beradaptasi dengan peristiwa terkini atau kejadian yang akan datang. Pola kepemimpinan di madrasah dengan model kepemimpinan transformatif menjadikan seorang kepala madrasah yang katalisator, inovator, motivator, goal planer, aktivator, action planer, leader, panutan, motivator, perencana aksi, perencana tujuan, pemimpin serta penghubung, mempunyai visi dan sebagai agen perubahan, dan mampu menyesuaikan dengan perkembangan zaman.

\section{Kata Kunci: Model Kepemimpinan Transformatif, Pola Kepemimpinan Transformatif, Kepala Madrasah}

\section{A. Pendahuluan}

Revolusi Industri 4.0 sudah merubah total segala aspek kehidupan di berbagai bidang baik dari ekonomi, warga, budaya serta politik. Pada masa disrupsi digital seperti ini menjadikan masa depan sulit untuk diprediksi. Maka, tantangan terbesar pada masa ini adalah menghadapi ketidakpastian masa depan yang akan dihadapi. Hal ini menjadi sumber kegelisahan bagi banyak orang dan pemimpin, bahkan menjadi sumber ancaman bagi segala bentuk kemapanan termasuk dalam pendidikan.

Kepemimpinan menggambarkan salah satu elemen yang memastikan keberlangsungan dan pertumbuhan organisasi (tercantum organisasi pembelajaran). Kualitas pendidikan berada di tangan seorang kepala sekolah yang memiliki peran dalam memanajemen kebijakan. Kepala sekolah mempunyai kekuasaan untuk merumuskan dan memutuskan kebijakan, mengaplikasikan strategi yang dapat membentuk kualitas pembelajaran di sekolah. Ilmu pengetahuan dan teknologi (IPTEK) terus mengalami perkembangan di seluruh bidang disaat ini. Sehingga seorang pemimpin harus memiliki kepekaan terhadap perkembangan tersebut dan mampu mengarahkan organisasi yang dipimpinnya agar dapat menghadapi tantangan dan perubahan. ${ }^{1}$

Madrasah merupakan salah satu organisasi yang dinamis dan mampu menghadapi perubahan dan perkembangan yang terjadi. Untuk menghadapi hal tersebut maka dibutuhkan seorang pemimpin yang mampu menghadapi tantangan,

${ }^{1}$ Chaerul Rofik,"Kepemimpinan Transformasional dalam Lembaga Pendidikan Madrasah”, Jurnal Penelitian Agama, 20. No. 2 (2019), hlm. 204. 
mampu berinovasi dan memiliki kemauan untuk melakukan perubahan. Untuk meningkatkan kualitas pendidikan maka dibutuhkan seorang pemimpin atau kepala sekolah yang mampu berinovasi dengan memperhatikan kebutuhan masyarakat serta perkembangan jaman. Akan tetapi, masih banyak gaya kepemimpinan dalam pengimplementasiannya tidak semudah yang dibayangkan, karena setiap gaya kepemimpinan memiliki kelemahan dan kekurangan yang harus benar-benar dipahami dan diperhatikan. ${ }^{2}$

Permasalahan yang dihadapi oleh lembaga pendidikan khusunya di madrasah yaitu masih kurang dalam memanajemen madrasah, etika profesi, jumlah dan kualitas guru, kurikulum, sarana dan prasarana, dan kepala sekolah yang kurang memahami manajemen yang tepat dan kurang inovatif. Tidak hanya itu, kepemimpinan di madrasah juga masih belum menerapkan model kepemimpinan modern yang mampu membawa sebuah lembaga pendidikan untuk memperoleh hasil yang maksimal. Hal ini terjadi karena dalam pemilihan kepala madrasah dilakukan berdasarkan usia, kharismatik, aset yang dimilikinya, dan memiliki pengaruh kekuasaan di lingkungan masyarakat. ${ }^{3}$

Secara umum, sekolah Islam masih menghadapi sejumlah kendala baik dari sisi latar belakang peserta didik, dukungan sumber daya pendidikan yang beragam, kualitas akademik yang rendah, dan partisipasi masyarakat yang rendah. ${ }^{4} \mathrm{Hal}$ ini menjadi salah satu hambatan yang dominan pada kualitas proses dan hasil pendidikan. Fenomena ini mengindikasikan bahwa sekolah Islam masih tertinggal dibandingkan dengan sekolah umum yang berkoordinasi dengan kementerian pendidikan. ${ }^{5}$ Untuk mengatasi permasalahan-permasalahan tersebut maka seorang pemimpin harus menerapakan sebuah model kepemimpinan yang sesuai dengan kebutuhan masyarakat dan perkembangan jaman serta mampu berinovasi. ${ }^{6}$

2 Indah Komsiyah, "Kepemimpinnan Transformatif Perkembangan dan Implementasinya Pada Lembaga Pendidikan”, Ta'allum, 04. No. 02 (2016), hlm. 294.

3 Arief Sukino, "Kepemimpinan Transformatif dalam Pengembangan Manajemen Madrasah Beroriaentasi Mutu”, An-Nidzam., 03. No. 01 (2016), hlm. 83-84.

${ }^{4}$ Asmiyati, "Model Kepemimpinan Kepala Madrasah dalam Meningkatkan Mutu Sumber Daya di Madrasah Ibtidaiyah Ma’arif Giriliyo I Wukirasari Imogiri Bantul”, Jurnal Pendidikan Madrasah. 3. No. 1 (2018): 43.

${ }^{5}$ Ibid, hlm 43.

6 Muhammad Shaleh Assingkily, Mesiono, "Karakteristik Kepemimpinan Transformasional di Madrasah Ibtidaiyah (MI) serta Relevansinya dengan Visi Pendidikan Abad 21”, Jurnal Manajemen Pendidikan Islam. 4. No. 1 (2019): 150. 
Model kepemimpinan merupakan model perilaku dimana pemimpin secara konsisten menerapkannya melalui orang lain dengan memberikan contoh perilaku yang baik dihadapan orang lain. ${ }^{7}$ Sejalan dengan Wahyudin, gaya kepemimpinan yang dianut mencakup kombinasi demokrasi tingkat rendah, perubahan, dan kepemimpinan otoriter yang dominan signifikan terhadap kinerja guru. ${ }^{8}$ Hal ini sejalan dengan pandangan Aminuddin bahwa peradaban lembaga pendidikan bergantung pada model kepemimpinan yang diterapkan oleh seorang pemimpin. ${ }^{9}$ Salah satu model kepemimpinan yang mampu beradaptasi dengan perubahan yang terjadi yaitu model kepemimpinan transformatif.

Model kepemimpinan transformatif memiliki ciri khas dimana seorang pemimpin dan bahwahan saling memberikan dorongan atau motivasi untuk mendapatkan hasil yang lebih dari yang direncanakan. Menurut Aan dan Cepi juga mengemukakan bahwa model kepemimpinan transformatif identik dengan inovasi dan kelangsungan hidup (viability). Model kepemimpinan transforrmatif jika dilihat dari perspektif humanistik akan menyerahkan pada perubahan dan menyesuaikan dengan perkembangan jaman. ${ }^{10}$ Menurut hadits Nabi Muhammad SAW, seorang pemimpin harus mencintai orang yang dipimpinnya, "Barangsiapa tidak mencintai atau mencintai orang lain, maka dia tidak akan dicintai atau dicintai oleh orang lain”. ${ }^{11}$

Setelah model kepemimpinan sudah ditentukan maka seorang kepala madrasah harus merumuskan sebuah pola kepemimpinan. Pola kepemimpinan yang diterapkan dalam penelitian Syarafudin yaitu ada empat pola diantara pola eksekutif, pengembangan, otokratis yang baik dan pola birokrat yang mamppu memberikan kontribusi positif dalama manajemen kelas. ${ }^{12}$ Hasil penelitian oleh

${ }^{7}$ I Made Sila dan Ida Bagus Rai, "Pengaruh Pola Kepemimpinan Kepala Sekolah dalam Mengatas Penyalah Gunaan Narkoba Pada Siswa di Sekolah Menengah Atas Dwijendra Denpasar”, Widya Accarya.. 9. No. 2 ( 2018): 3.

${ }^{8}$ Ujang Wahyudin,, “Pola Kepemimpinan Kepala Sekolah dalam Membangun Akhlak Peserta Didik”, Jurnal Tawazun. 11. No. 1 (2018): 70.

${ }^{9}$ M. Yusuf Aminuddin, "Model Kepemimpinan Transformatif (Kajian Kepemimpinn Transformatif di Lembaga Pendidikan Islam”, Al-Hikmah: Jurnal Studi Keislaman. 7. No. 2 (2017): 15-23.

10 Muhammad Shaleh Assingkily, Mesiono. "Karakteristik Kepemimpinan Transformasional di Madrasah Ibtidaiyah (MI) serta Relevansinya dengan Visi Pendidikan Abad 21”... 150.

11 Nurlena, “Tugas dan Fungsi Kepemimpinan Kepala Madrasah di Madrasah Ibtidaiyah”, Jurnal Pendidikan Islam. 4. No. 1 (2020): 24.

12 Syarafudin, "Pola Kepemimpinan Kepala Sekolah dan Kompetensi Guru dalam Pengelolaan Pembelajaran di Sekolah Menengah”, Jurnal Ilmiah Profesi Pendidikan. 4. No. 22 (2019): 133. 
Bustari, dkk (2020) mengindikasikan bahwa kepemimpinan transformasional dominan positif pada lembaga pendidikan Islam menambah kinerja sumber daya manusia (SDM), dan menginspirasi pimpinan lain guna memimpin suatu organisasi, baik lembaga pendidikan umum maupun lembaga pendidikan Islam. ${ }^{13}$ Kepemimpinan transformatif yang di terapkan di Madrasah Minoritas Muslim Papua Barat menunjukkan bahwa memberikan dampak yang sangat signifikan yaitu adanya semangat dari peserta didik, komitmen dari guru, dan penegasan dari stakeholder lain. ${ }^{14}$

Berdasarkan permasalahan-permasalahan diatas, maka peneliti tertarik untuk melakukan penelitian tentang "Model Kepemimpinan Transformatif dalam Mengembangakan Pola Kepemimpinan di Madrasah Ibtidaiyah”. Tujuan penelitian ini yaitu untuk mendesain pola kepemimpinan di Madrasah Ibtidaiyah dengan model kepemimpinan transformatif.

\section{B. Pembahasan}

\section{Kajian Teori}

\section{a) Kepemimpian Pendidikan}

Kepemimpinan ialah kemampuan guna menggerakkan, memotivasi, mengarahkan, mempengaruhi, mengajak, membimbing, menasehati, membina, melatih, dan merintih dengan tujuan supaya manusia sebagai unsur dari organisasi inginkan bekerja dalam rangka menjangkau tujuan dirinya sendiri maupun organisasi secara efesien dan efektif. ${ }^{15}$ Adapun pendapat tersebut berasumsi bahwa kepemimpinan adalah cara pemimpin untuk memprovokasi perilaku bawahan supaya mau berkoloborasi dan bekerja secara produktif untuk menjangkau tujuan organisasi. $^{16}$ Kepemimpinan merupakan suatu proses pengelolaan,

\footnotetext{
${ }^{13}$ Bustari, dkk. “Kepemimpinan Transformatif dalam Lembaga Pendidikan Islam”. Produ: Prokurasi Edukasi Jurnal Manajemen Pendidikan Islam. 1. No. 2 (2020): 166-173.

${ }^{14}$ Ismail Suardi Wekke, Efa Rubuwati dan Siti Nurjannah, "Kepemimpinan Transformatif di Madrasah Minoritas Muslim Papua Barat”, J_MPI (Jurnal Manajemen Pendidikan Islam). 2. No. 1. (2017): 8.

${ }^{15}$ Noor Septaningrum, Pola Kepemimpinan Kepala Sekolah di SDIT Cahaya Bangsa Mijen Semarang. Skripsi. Fakultas Ilmu Tarbiyah dan Keguruan Universitas Islam Negeri Walisongo Semarang. (2015): 11.

${ }^{16}$ Luluk Indarti, “Dimensi-dimensi Kepemimpinan Transformatif Pendidikan Islam”, Ta'allum: Jurnal Pendidikan Islam. 05. No. 01( 2017): 24-25.
} 
pengawasan, pemberdayaan yang dilakukan oleh seorang pemimpin terhadap sesuatu yang dipimpinnya, dengan tujuan untuk meningkatkan sumberdaya manusia sehingga tujuan bersama yang diharapkan dapat tercapai. ${ }^{17}$

Kepemimpinan didefinisikan sebagai suatu kekuatan yang dipakai untuk memprovokasi serta menggerakkan orang lain. Jadi kepemimpinan ialah suatu perangkat yang dipakai untuk memprovokasi orang lain supaya bersedia mengerjakan sesuatu dengan sukarela. ${ }^{18}$ Kepemimpinan pendidikan adalah suatu keterampilan dalam proses menggerakkan, mengkoordinasikan, mempengaruhi, dan memotivasi orang lain yang sehubungan dengan pendidikan dan pengajaran, sehingga pekerjaan yang dilaksanakan dapat dilakukan secara efektif untuk menjangkau tujuan pendidikan dan pengajaran. ${ }^{19}$ Kepemimpinan pendidikan ialah salah satu jenis kesiapan, keterampilan yang dipunyai seseorang dalam proses mempengaruhi, mendorong, membimbing, dan menggerakkan orang lain yang sehubungan dengan pendidikan dan pengajaran, sampai-sampai semua pekerjaan dapat dilaksanakan secara efektif untuk menjangkau tujuan pendidikan. ${ }^{20}$

Kepemimpinan pendidikan dapat dipahami sebagai orang yang telah dipersiapkan dalam proses mempengaruhi, mendorong, membimbing, membimbing dan memobilisasi orang lain terkait dengan penyelenggaraan dan pengembangan pendidikan dan pengajaran, sehingga segala kegiatan dapat didasarkan pada tujuan pendidikan dan pengajaran. Efektif dan efisien. ${ }^{21}$ Oleh karena itu kepemimpinan pendidikan adalah kemampuan seseorang untuk mempengaruhi, menginspirasi, membimbing, membimbing, dan melaksanakan pengembangan atau inovasi lembaga

\footnotetext{
${ }^{17}$ Muhammad Shaleh Assingkily dan Mesiono, "Karakteristik Kepemimpinan Transformasionaldi Madrasah Ibtidaiyah (MI) serta Relevansinya dengan Visi Pendidikan Abad 21,” ... 150.

18 Ibid, 17. ... 11 .

${ }^{19}$ Noor Septaningrum, Pola Kepemimpinan Kepala Sekolah di SDIT Cahaya Bangsa Mijen Semarang.

${ }^{20}$ Isti Fatonah, “Kepemimpinan Pendidikan”, Jurnal Tarbawiyah. 10. No. 2 (2013): 112.

21 Arief Sukino, "Kepemimpinan Transformatif dalam Pengembangan Manajemen Madrasah Beroriaentasi Mutu”... 92.
} 
pendidikan mulai dari perencanaan, pelaksanaan, dan proses pembelajaran guna mencapai tujuan pendidikan yang telah ditetapkan. Kepemimpinan kepala sekolah merupakan upaya kepala sekolah untuk mempengaruhi, mendorong, membimbing, membimbing, dan menggerakkan guru, siswa, staf, orang tua, wali siswa, dan masyarakat untuk mewujudkan visi dan misi yang telah ditetapkan. ${ }^{22}$

\section{b) Pola Kepemimpinan}

Berdasarkan keterangan dari Muyadi, pola ialah model, bentuk, contoh, pedoman, desain, dan pondasi kerja. Model kepemimpinan merupakan format atau model perilaku pimpinan untuk mempengaruhi orang lain. ${ }^{23}$ Model kepemimpinan di anggap sebagai prasyarat sebagai keberhasilan, pencapaian dan pencapaian destinasi organisasi. ${ }^{24}$ Semakin efektif model kepemimpinan yang dianut oleh kepala sekolah maka semakin kondusif untuk peningkatan kinerja guru dalam tatanan kerja madrasah. ${ }^{25}$

Gaya kepemimpinan kepala sekolah akan dominan pada sistem kepandaian yang ditentukan dengan musyawarah dan dilakukan oleh pemimpin. Keberhasilan kepemimpinan bisa dinilai dari peran, fungsi dan tanggung jawab yang dilaksanakan dalam model kepemimpinan yang diterapkan di pusat kepemimpinan. ${ }^{26}$ Sekolah atau kepala sekolah Madrasah bisa mngadopsi sejumlah gaya kepemimpinan yaitu, kepemimpinan karismatik, kepemimpinan transformasional, kepemimpinan transaksional dan kepemimpinan visioner. ${ }^{27}$

\footnotetext{
${ }^{22}$ Syarafudin, "Pola Kepemimpinan Kepala Sekolah dan Kompetensi Guru Dalam Pengelolaan Pembelajaran di Sekolah Menengah”, ... 129.

${ }^{23}$ Noor Septaningrum. Pola Kepemimpinan Kepala Sekolah di SDIT Cahaya Bangsa Mijen Semarang. ...(2015): 13 .

${ }^{24}$ Lusila Parida, Sirilus Sirhi, dan Daniel Dike, "Pola Kepemimpinan Kepala Sekolah dalam Penguatan Karakter di Sekolah Kota Sintang Kalimantan Barat,” JIKAP PGSD: Jurnal Ilmiah Ilmu Kependidikan, 6. no. 2 (2020): 5 .

${ }^{25}$ Sudharto. "Pengaruh Pola Kepemimpinan Kepala Sekolah dan Suasana Kerja Terhadap Kinerja Guru”, JMP. 1. No.2 (Agustus 2012): 221.

${ }^{26}$ Ujang Wahudi, E. Bahrudin dan Maemuah Sa’diyah, “Kepala Sekolah dalam Membangun Akhlak Peserta didik... 68.

27 Noor Septaningrum. Pola Kepemimpinan Kepala Sekolah di SDIT Cahaya Bangsa Mijen Semarang...(2015): 14.
} 


\section{c) Kepemimpinan Transformatif}

Kepemimpinan transformatif adalah kepemimpinan yang dapat membentuk suatu perubahan yang esensial serta dilandasi dengan nilainilai agama, sistem dan budaya untuk dapat menciptakan suatu inovasi dan kreativitas anggotanya sebagai upaya agar visi yang telah ditentukkan dapat tercapai. Kepemimpinan transformatif adalah salah satu jenis kepemimpinan yang menonjolkan pada perlunya sistem nilai yang digunakan untuk meningkatkan kesadaran anggotanya mengenai permasalahan etis, memobilitasi energi dan sumber daya yang mampu membawa perubahan bagi institusi. ${ }^{28}$

Kepemimpinan transformatif adalah salah satu bentuk dari model kepemimpinan yang di dalamnya mengandung proses seorang pemimpin beserta bawahannya bersama-sama berusaha mencapai pada tingkat moralitas dan motivasi yang lebih tinggi. Artinya seorang pemimpin berusaha untuk membentuk kesadaran bawahannya melalui seruan-seruan tentang cita-cita yang besar serta moralitas yang tinggi seperti kebersamaan, kejayaan, dan kemanusiaan. Sedangkan para pengikut pimpinan transformatif akan termotivasi untuk melakukan hal-hal yang lebih baik dalam rangka mancapai sasaran organisasi. ${ }^{29}$ Pemimpin yang transformatif lebih berperan sebagai mentor yang dapat menampung pendapat dari para bawahanya dan lebih menekankan pada bagaiamana merevitalisasikan institusi atau lembaganya. ${ }^{30}$

Kepemimpinan transformatif menuntut pimpinan yang memiliki kemampuan untuk berkomunikasi secara baik, khususnya dalam komunikasi persuasif dengan pengikutnya serta kemampuan untuk memberi motivasi kepada bawahannya agar mereka dapat menjalankan tanggung jawab yang mereka miliki lebih dari yang diharapkan. Pemimpin suatu lembaga pendidikan yang dapat melaksanakan transformasi

${ }^{28}$ Luluk Indarti, “Dimensi-dimensi Kepemimpinan Transformatif Pendidikan Islam”, ... 28-29.

${ }^{29}$ Suminto, “Karakteristik Kepemimpinan Transformatif,” Pedagogy 4. No. 1. (2017): 6.

${ }^{30}$ Bustari, Muhammad Arif, Nurma Yunita, dan Novira Chintya Sari, "Kepimimpinan Transformatif dalam Lembaga Pendidikan Islam” ... 168. 
kepemimpinan, maka ia pada dasarnya telah mampu menjadikan potensipotensi yang dimiliki institusinya untuk digunakan sebagai usaha untuk meningkatkan mutu, proses, dan hasil pendidikannya. ${ }^{31}$

Pemimpin transformatif merupakan seseorang yang harus selalu tanggap dengan potensi-potensi dan sumber daya yang organisasinya miliki khususnya sumber daya manusianya. Pemimpin transformative piawai dalam menjadikan semua potensi yang organisasinya miliki untuk mencapai tujuan organisasi secara maksimal. Kepemimpinan pendidikan transformatif piawai dalam melihat perubahan-perubahan yang terjadi di luar organisasi yang dapat menuntut perubahan bagi organisasinya serta piawai menggerakkan bawahannya selaras dengan visi dan misi yang dimiliki organisasi. ${ }^{32}$

Karakteristik kepemimpinan transformatif, adalah sebagai berikut: a) pemimpin adalah motor penggerak menuju perubahan; b) mempunyai visi yang besar; c) menumbuhkan kesadaran kolektif mengenai pentingnya tujuan organisasi untuk dicapai; d) siap menghadapi risiko dari keputusankeputusan yang telah diambil dengan pertimbangkan yang matang; e) ramah dan tanggap dengan perkembangan dan pengalaman yang baru; f) percaya dengan kamampuan yang dimiliki anggotanya; g) kepentingan organisasi menjadi sesuatu yang diprioritaskan sehingga baik anggota maupun pemimpin harus siap untuk berkorban; h) lebih memprioritaskan motivasi yang bersifat intrinsik dari pada ekstrinsik; dan i) pimpinan menjadi pembimbing bagi perilaku para anggotanya untuk menuju pada kultur dan pengembangan organisasi. ${ }^{33}$ Kepemimpinan transformatif memiliki beberapa prinsip, meliputi motivasi, simplikasi, mobilitas, fasilitas inovasi, tanggap terhadap perubahan-perubahan dan memiliki tekad yang kuat. ${ }^{34}$

31 Arief Sukino, "Kepemimpinan Transformatif dalam Pengembangan Manajemen Madrasah Beroriaentasi Mutu”, ... 94.

32 Syafnan, “Kepemimpinan Transformatif di Lembaga Pendidikan”, Jurnal Ta'dib 13. No. 1. (2010): 67.

${ }^{33}$ Muhammad Shaleh Assingkily, "Karakteristik Kepemimpinan Transformatif fi Madrasah Ibtidaiyah (MI) serta Relevansinya dengan Visi Pendidikan Abad 21",... 155.

34 Indah Komsiyah, "Kepemimpinnan Transformatif Perkembangan dan Implementasinya Pada 
Pemimpin transformatif memiliki ciri-ciri sebagai berikut: a) pemimpin transformatif selalu menjadi pembimbing bagi pengikutnya untuk dapat mengenali berbagai macam persoalan dan memberi solusi mengenai cara pememecahannya; b) mempunyai kharisma; c) pemimpin transformatif selalu memotivasi dan meginspirasi pengikutnya melalui komunikasi yang efektif; d) pemimpin transformatif mempunyai kepeduliaan dan perhatian kepada setiap anggotanya; e) pemimpin transformatif merupakan sosok selalu memberi teladan bagi anggotanya; f) pemimpin transformatif selau berusaha untuk meningkatkan kapasitas anggotanya agar dapat mandiri dan tidak selalu bergantung pada pemimpinnya. ${ }^{35}$

\section{2) Metode Penelitian}

Metode penelitian yang peneliti gunakan dalam penelitian ini adalah metode penelitian kualitatif. Sugiyono mendefinisikan metode penelitian kualitatif sebagai metode penelitian yang digunakan oleh peneliti untuk meneliti suatu kondisi objek yang alamiah, di mana instrumen kunci dalam penelitian kualitatif adalah peneliti itu sendiri. ${ }^{36}$ Penelitian ini menggunakan pendekatan studi kepustakaan (library research). Menurut Hamzah penelitian kepustakaan yaitu kegiatan analisa teks atau wacana untuk mendapatkan fakta yang tepat kemudian disimpulkan dalam bentuk bangunan konsep baru atau teori baru. ${ }^{37}$

Teknik analisis pada penelitian ini yaitu dengan analisis isi yang dilakukan dengan proses membandingkan, memilih, menganalisis dan menggabungkan berbagai pengertian sehingga ditemukan yang lebih relevan. Teknik Pengumpulan data yang digunakan oleh peneliti dalam penelitian ini melalui dokumentasi dari berbagai macam sumber yang meliputi buku, jurnal, dan dokumen yang relevan dengan penelitian. Sumber data dalam penelitian ini meliputi data sekunder dan data primer. Data primer yaitu jurnal-jurnal yang

\footnotetext{
Lembaga Pendidikan”, ... 307.

${ }^{35}$ Bustari, dkk, “Kepimimpinan Transformatif dalam Lembaga Pendidikan Islam”... 168.

${ }^{36}$ Sugiyono, Metode Penelitian dan Pengembangan (Research and Development/ R\&D), (Bandung: Alvabeta, 2019): 16.

37 Amir Hamzah, Metode Penelitian \& Pengembangan (Research \& Development) Uji Produk Kuantitatif dan Kualitatif Proses dan Hasil Dilengkapi Contoh Proposal Pengembangan Desain Uji Kualitatif dan Kuantitatif (Malang: CV. Literasi Nusantara, 2019): 167.
} 
berkaitan dengan model kepemimpinan transformatif sedangkat data sekunder yaitu buku, artikel dan jurnal yang membahas tentang pola kepemimpinan di MI yang menggunakan kepemimpinan transformatif.

Tabel 1. Jurnal-jurnal

Tentang Model Kepemimpinan Transformatif

\begin{tabular}{|c|c|c|c|}
\hline No. & Nama Penulis & Jurnal & Tahun \\
\hline 1. & Syafnan & Ta'dib & 2010 \\
\hline 2. & Indah Komsiyah & Ta’allum & 2016 \\
\hline 3. & Arief Sukino & An-Nidzam & 2016 \\
\hline 4. & Iwa Kuswaeri & Tarbawi & 2016 \\
\hline 5. & Abdul Kholiq & Jurnal Ilmiah Studi Islam & 2017 \\
\hline 6. & $\begin{array}{l}\text { M. Yusuf } \\
\text { Aminuddin }\end{array}$ & Al-Hikmah: Jurnal Studi Keislaman & 2017 \\
\hline 7. & $\begin{array}{l}\text { Ismail Suardi } \\
\text { Wekke, Efa } \\
\text { Rubawati, dan Siti } \\
\text { Nurjannah }\end{array}$ & $\begin{array}{l}\text { J_MPI : Jurnal Manajemen } \\
\text { Pendidikan Islam }\end{array}$ & 2017 \\
\hline 8. & Luluk Indrarti & Ta’allum: Jurnal Pendidikan Islam & 2017 \\
\hline 9. & Suminto & Pedagogy & 2017 \\
\hline 10. & Chaerul Rofik & JPA & 2019 \\
\hline 11. & $\begin{array}{l}\text { Muhammad Shaleh } \\
\text { Assingkily }\end{array}$ & $\begin{array}{l}\text { Manageria: Jurnal Manajemen } \\
\text { Pendidikan Islam }\end{array}$ & 2019 \\
\hline 12. & Bustari, dkk & $\begin{array}{l}\text { Produ: Prokurasi Edukasi Jurnal } \\
\text { Manajemen Pendidikan Islam }\end{array}$ & 2020 \\
\hline
\end{tabular}

\section{3) Hasil Penelitian}

\section{a) Kepemimpinan Transformatif}

Kepemimpinan merupakan suatu proses untuk mempengaruhi orang lain atau kelompok bawahan agar tujuan bersama dapat dicapai secara efektif dan efisien. Kepemimpinan yang relevan dengan perkembangan zaman yaitu sekolah yang memiliki manajemen yang baik dan diharapkan dapat meningkatkan pendidikan melalui kepemimpinan yang memiliki visi dan fokus pada keadaan masa depan. ${ }^{38}$ Kepemimpinan merupakan segala tindakan untuk mempengaruhi dan memobilisasi orang-

${ }^{38}$ Abdul Kholiq. Model Kepemimpinan Transformatif Kepala Madrasah. Jurnal Ilmiah Studi Islam. 17. No. 1. (Desember 2017): 41. 
orang dalam usaha bersama agar tujuan dapat dicapai. ${ }^{39}$

Kepala madrasah sebagai pemegang kunci untuk melakukan pengembangan dan kemajuan madrasah, meningkatkan tanggungjawab dan otoritasnya dalam kebijakan yang sudah ada dituangkan ke dalam program kerja madrasah, kurikulum, keputusan, bertanggungjwab dalam meningkatkan akuntabilitas, keberhasilan peserta didik dan keberhasilan program. Tugas dan fungsi kepala sekolah maka pembaruan pola kepemimpinan menjadi sebuah kebutuhan yang harus dipenuhi. Untuk mengimplementasikan kepemimpinan di lembaga pendidikan Islam ada banyak hal yang perlu diperhatikan diantaranya adanya kemampuan untuk mencipakan kekuasaan yang berbeda untuk mempengaruhi perilaku anggota melalui berbagai strategi, melibatkan bawahan atau pengikut dan kepemimpinan melibatkan pembagian kekuasaan yang seimbang antara pemimpin dan anggota kelompok. ${ }^{40}$

Model kepemimpinan transformatif dimana seorang pemimpin mempengaruhi kinerja bawahan, karena seorang pemimpin transformasional mempunyai visi yang konkret dan gambaran yang menyeluruh tentang organisasi di masa depan ketika telah tercapainya semua tujuan. ${ }^{41}$ Hal ini senada dengan pendapat Komsiyah yaitu bentuk kepemimpinan transfomatif adalah suatu bentuk kepemimpinanan di mana pemimpin dapat memberi motivasi kepada para bawahannya supaya mereka dapat maksimal dalam menjalankan pekerjaan mereka. Bentuk kepemimpinan seperti ini mempunyi energi dan semangat yang tinggi dan memotivasi pengikutnya untuk mencapai tujuan dari lembaga yang dipimpinnya. ${ }^{42}$

Menurut Bass dan Aviola dalam Rofik ada empat komponen dalam menerapkan kepemimpinan transformatif meliputi Idialized Influence

\footnotetext{
${ }^{39}$ M. Yusuf Aminuddin,”Model Kepemimpinan Transformatif (Kajian Kepemimpinan Transformatif di Lembaga Pendidikan Islam.... 17.

${ }^{40}$ M. Yusuf Aminuddin, "Model Kepemimpinan Transformatif (Kajian Kepemimpinan Transformatif di Lembaga Pendidikan Islam”, ... 17.

${ }^{41}$ Syafnan. Kepemimpinan Transformatif di Lembaga Pendidikan. Ta'dib. Vol. 13. No. 1. Juni 2010.65.

${ }^{42}$ Bustari, dkk, “Kepemimpinan Transformatif dalam Lembaga Pendidikan Islam”, ... 166-173.
} 
(perilaku yang memberikan dampak rasa hormat dan percaya diri), Inspirational Motivation (perilaku yang selalui memberikan tantangan dan perhatian kepada bawahannya), Intellectual Stimulation (pemimpin yang mampu mempraktekkan inovasi-inovasi), dan, Individualized Consideration (Pemimpin yang mampu mencitrakan dirinya sebagai sosok yang penuh perhatian dan pendengar yang baik serta dapat menindaklanjuti segala maukkan yang diberikan dari bawahan). ${ }^{43}$

Berikut ini gambar model kepemimpinan transformatif menurut Ownes, yaitu: ${ }^{44}$

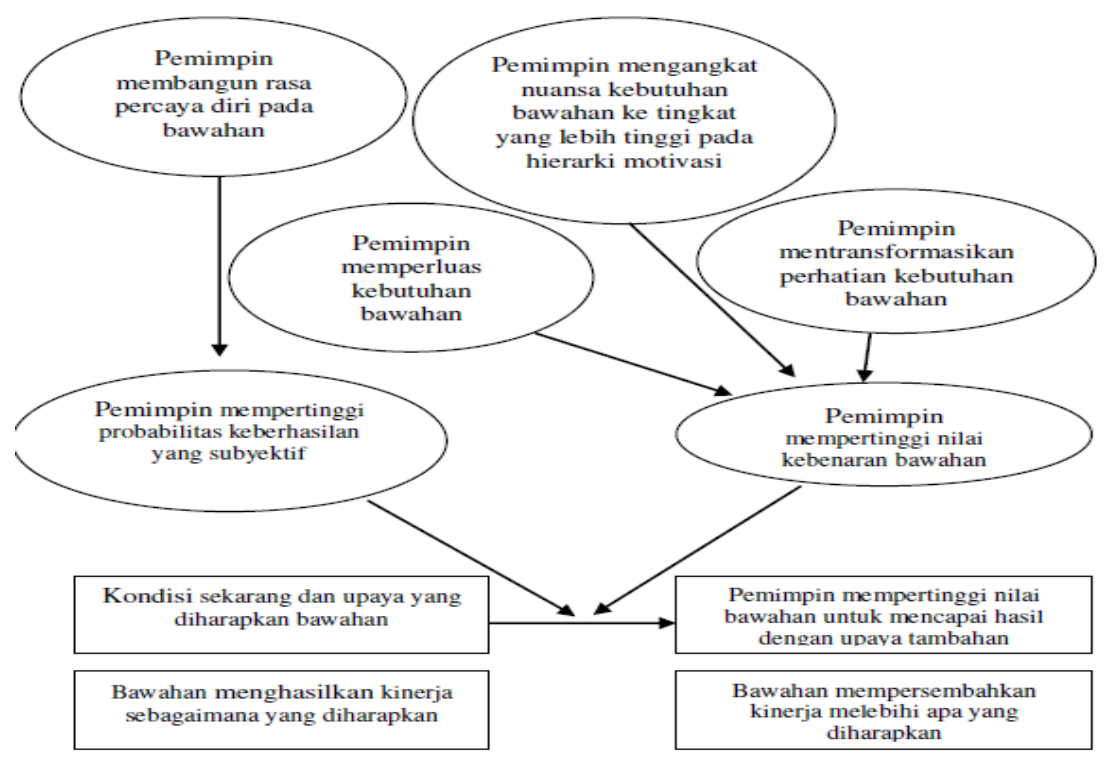

Gambar 1. Model Kepemimpinan Transformatif

Berdasarkan penelitian yang dilakukan Wekke menunjukkan bahwa pemimpin dalam mengimplementasikan kepemimpinan transformatif dalam lembaga pendidikan ada dua komponen yang mempengaruhi dalam peningkatan mutu dan kualitas madrasah yaitu pendidik dan peserta didik. ${ }^{45}$ Penelitian yang dilakukan oleh Komsiyah menunjukkan bahwa dalam menerapkan kepemimpinan transformatif di lembaga pendidikan dapat 217.

${ }^{43}$ Chaerul Rofik, ”Kepemimpinan Transformasional dalam Lembaga Pendidikan Madrasah”, ... 216-

${ }^{44}$ Syafnan, “Kepemimpinan Transformatif di Lembaga Pendidikan”... 65.

${ }^{45}$ Ismail Suardi Wekke, Efa Rubuwati, dan Siti Nurjannah, "Kepemimpinan Transformatif di Madrasah Minoritas Muslim Papua Barat”,... 7. 
terwujud dengan efktif apabila melakukan hal-hal seperti membuat visi yang menarik dan jelas, menjelaksan bagaimana visi tersebut dapat dicapai, tindakan simbolis dan dramatis untuk menekankan nilai-nilai yang dianggap penting, menunjukkan keyakinan kepada pengikut, memimpin dengan memberikan contoh yang baik, bertindak secara optimis, dan memberikan otoritas kepada orang-orang demi tercapainya visi tersebut. ${ }^{46}$

Sifat-sifat kepemimpinan transformatif meliputi karismatik, inspirasi, kemahiran menstimulasi intelektual para bahawahan secara aktif dengan memberikan dorongan dan menilai keadaan lama serta mengikuti perspektif yang baru, dan sifat kooperatif secara individu. ${ }^{47}$ Oleh karena itu, agar dapat menjadi pemimpin sekolah atau kepala sekolah ang dapat beradap tasi dengan perubahan dan perkembangan aman maka perlu mengembangkan sifat-sifat kepemimpinan transformatif pada dirinya.

\section{b) Pola Kepemimpinan dengan Model Kepemimpinan Transformatif di Madrasah Ibtidaiyah}

Madrasah disebut dengan tulang punggu dari kokohnya bangunan agama Islam di Nusantara. Madrasah sebagai harapan dari masyarakat muslim untuk membentuk karakter yang baik, berakhlakul karimah, sehingga madrasah harus tampil lebih kokoh agar mampu mewujudkan hal tersebut. Untuk mewujudkan tujuan pendidikan nasional maka madrasah perlu didukung oleh sumber daya yang unggul khususnya kepla sekolah. Saat ini madrasah harus melakukan perubahan dari model kepemimpinan tradisional ke model kepemimpinan yang mampu menyesuaikan dengan perubahan dan perkembangan zaman. ${ }^{48}$

Pemimpin merupakan orang yang berada dibagian yang paling pertama untuk melakukan sesuatu atau bergerak melakukan sesuatu, mengambil langkah pertama, berjalan di depan, berbuatpaling dulu,

\footnotetext{
46 Indah Komsiyah. Indah Komsiyah, "Kepemimpinnan Transformatif Perkembangan dan Implementasinya Pada Lembaga Pendidikan”, ... 307-313.

47 Iwan Kuswaeri, “Kepemimpinan Transformasional Kepala Sekolah”, Tarbawi. 2. No. 02 (JuliDesember 2016): 6.

48 Arief Sukino, "Kepemimpinan Transformatif dalam Pengembangan Manajemen Madrasah Berorientasi Mutu”, ...91.
} 
memulai sebuah tindakan, menunjukkan pikiran atau pendapat, membimbing, membimbing, dan mempengaruhi orang lain agar mau bergerak. $^{49}$ Senada dengan pendapat Bustari, dkk kemampuan mengarahkan dan mempengaruhi sekelompok orang harus dimiliki oleh seorang pemimpin. ${ }^{50}$

Pemimpin di sebuah lembaga pendidikan Islam khususnya Madrasah Ibtidaiyah mampu memberikan motivasi bahawannya agar dapat memberikan semangat kepada bawahannya dalam melaksanakan pekerjaanya secara optimal dan mampu memberikan solusi terkait masalah yang dihadapi lembaga tersebut. Kepemimpinan transformatif di lembaga pendidikan Islam mengontribusikan hal yang positif terhadap orang yang ada di bawah pimpinannya sehingga mereka dapat melaksanakan hal tersebut dan memberikan dampak pada sebuah pekerjaan yang baik. Seorang pemimpin di lembaga Islam juga harus bisa mencerminkan perilaku yang baik kepada bawahannya, menjadikan agama Islam menjadi dasar dan pedoman dalam menjalankan suatu lembaga pendidikan, berbuat adil dan tidak membeda-bedakaan dalam segal sesuatu, dan memberikan motivasi serta masukan kepada para bawahannya agar melaksanakan pekerjaan secara maksimal dan bisa mencapai tujuan lembaga pendidikan Islam. ${ }^{51}$

Kinerja guru dalam melaksanakan kegaiatan belajar dan kemampuan mengevaluasi pembeajaran karena guru membuat penilaian dengan kekurangan dan perkembangan masing-masing peserta didik dipengaruhi oleh gaya kepemimpinan kepala madrasah yang diterapkan. ${ }^{52}$ Menurut Kuswaeri, kepala madrasah yang menerapkan kepemimpinan transformatif mampu mencapai tujuan pembelajaran maka dapat dilakukan dengan mengganti energi sumber daya baik manusia, instrumen, ataupun

49 Arief Sukino, "Kepemimpinan Transformatif dalam Pengembangan Manajemen Madrasah Berorientasi Mutu”,... .91.

${ }^{50}$ Bustari, dkk, “Kepemimpinan Transformatif dalam Lembaga Pendidikan Islam”, ... 168.

${ }^{51}$ Bustari, dkk, "Kepemimpinan Transformatif dalam Lembaga Pendidikan Islam”, ...172.

52 Wasik Fajar Rahmawati, Pola Kepemimpinan Kepala Sekolah Terhadap Kinerja Guru, Skripsi. Program Studi Pendidikan Anak Usia Dini, Fakultas Keguruan dan Ilmu Pendidikan, Universitas Muhammadiyah Surakarta. (2020): 12. 
kondisi yang terjadi di lingkungan sekitar. Kepala madrasah transformatif memiliki kharismatik, visi, agen perubahan, merangsang intelektual, empatik dan menumbuhkan kreativitas. Penerapan kepemimpinan transformatid menciptakan proses pembelajatan dengan budaya dan iklim sebuah efektif dan tercapainya pretasi belajar peserta didik yang memuaskan. ${ }^{53}$

Menurut Rofik, prinsip-prinsip yang harus diperhatikan oleh kepala madrasah dalam menerapkan kepemimpinan transformatif, yaitu menjadi panutan bagi guru dan karyawannya, memberikan motivasi keselurug guru dan karyawannya, mengembangkan inovasi dan kreativitas guru dan karyawan dengan mengembangan kemampuan berpikir kritis serta pemecahan masalah agar menciptakan madrasah ke arah yang lebih baik, dan mampu menjadi pelatih dan penasehat serta sebagai pemberdaya bagi guru dan karyawannya. Kepala madrasah harus mampu menyesuaikan diri secara terus-menerus dan selalu siap bersedia dengan adanya perubahan yang sedang terjadi atau yang akan terjadi. Fokus akan perubahan pemimpin transformatif tetap konsisten karena tidak mnghalangi dalam proses menentukan metode-metode baru. ${ }^{54}$

Berdasarkan penelitian yang dilakukan Assingkily menunjukan bahwa kepemimpinan transformatif yang dilaksanakan melalui Idealized Influence, Inspirational Motivation, Intellectual Stimulation, dan Individual Consideration dan dengan memperhatikan 4C (Critical thinking and problem solving, creativity and innovation, communication, and collaboration) menuju 3 visisi pendidikan abad 21 yaitu life and career skills, learning and innovation skills, information, media and technology skills, dipandang tepat diterapkan di madrasah ibtidaiyah dan madrasah ppada umumnya. Hal ini disebabkan kepemimpinan transformatif memiliki dan menerapkan prinsip dimana seorang pemimpin harus bersifat temporal disuatu lembaga sehingga menuntut untuk melakukan hal yang lebih baik

${ }^{53}$ Iwan Kuswaeri, “Kepemimpinan Transformasional Kepala Sekolah”, ...3-12.

${ }^{54}$ Chaerul Rofik,’Kepemimpinan Transformasional dalam Lembaga Pendidikan Madrasah”,... 221224. 
untuk selanjutnya, dan model kepemimpinan ini sesuai dengan kebijakan menyerahkan sebagian wewenang pemimpin kepada bawahan atau desentralisasi pendidikan dan otonomi daerah. ${ }^{55}$

Sesuai dengan pendapat Indarti yang menyatakan bahwa kepemimpinan transfromatif kepala madrasah merupakan penentu atau ujung tombak dan menjadi pengemudi yang menunjukkan jalan sebuah lembaga pendidikan mau dibawa kemana, karena pemimpin dan pengikutnya memiliki motivasi yang tinggi dan saling meningkatkan moralitasnya. Madrasah tanpa adanya pemimpin yang mampu menyesuaikan dirinya dengan berbagai perubahan dan kreatif akan akan menjadi penyebab kurang optimalnya lembaga pendidikan bahkan kemunduran madrasah akan dialami. ${ }^{56}$

Pola kepemimpinan kepala madrasah harus mengikuti perkembangan IT, yang mewajibkan semua guru wajib menguasai IT, bahasa Inggris dan program peningkatan kualitas pembelajaran yang diaksanakan. ${ }^{57}$ Senada dengan pola kepemimpinan transformatif yang telah diteliti oleh Septaningrum yaitu kepala madrasah menjadi katalisator dalam agen perubahan atau berperan dalam perubahan sistem ke arah yang lebih baik yaitu menginovasi budaya dan strategi-strategi sebuah organissi serta memformuasikan sebuah visi dengan mengembangkan komitmen terhadapnya. Kepala madrasah berusaha agar sumber daya manusia yang ada menjadi meningkat, memberikan reaksi yang menimbulkan semangat dan maksimal daya kerja dan selalu tampil sebagai pelopor serta pembawa agen perubahan. ${ }^{58}$

Pola kepemimpinan di madrasah menurut syarafudin yaitu membuat proses pembelajaran menjadi lebih efektif melalui pengelolaan

\footnotetext{
${ }^{55}$ Muhammad Shaleh Assingkily, "Karakteristik Kepemimpinan Transformatif fi Madrasah Ibtidaiyah (MI) serta Relevansinya dengan Visi Pendidikan Abad 21”, ...166.

${ }^{56}$ Luluk Indarti, “Dimensi-dimensi Kepemimpinan Transformatif Pendidikan Islam”, ... 34.

57 Dira Nadira, "Pola Kepemimpinan Kepala Sekoah di Yayasan Pendidikan Islam Amir Hamzah", Jurnal Benchmarking: Jurnal Manajemen Pendidikan Islam, 1. No. 1. (2017): 21. 102.

${ }^{58}$ Noor Septaningrum. Pola Kepemimpinan Kepala Sekolah di SDIT Cahaya Bangsa Mijen Semarang...
} 
kelas yang efisien. ${ }^{59}$ Pola kepemimpinan transformatif leadership dan cultural leadership dari hasil penelitian Parida yaitu kepala madrasah perlu mengembakan pola kepemimpinan tersebut agar memberi ruang inovasi program-program penguatan karakter dan memperkuat implementasi Kurikulum 2013 yang berbasis karakter, literasi, 4 C (communication, colaboration, creativity, critical thinking),dan HOTS (high order thinking skills). ${ }^{60}$ Pola kepemimpinan yang bisa diterapkan oleh kepala madrasah seperti yang diteliti oleh Wahyudi yaitu memberikan kebebasan berfikir dan memberikan pendapat, melakukan musyawarah, adil dan lain sebagainya.

Pola kepemimpinan transformatif yang dilaksanakan untuk menentukan setiap kebijakan atau keputusan yang dibuat, baik yang strategis ataupun yang non strategis. ${ }^{61} \mathrm{Hal}$ ini senada denngan Sila dan Rai yaitu pola kepemimpinan transformatif yang diterakpan memberikan dampak yaitu kepala sekolah dengan sangat efektif dan dapat mempengaruhi perilaku guru, membimbing peserta didik ke arah yang positif. ${ }^{62}$ Pola kepemimpinan yang ditemukan oleh Wekke, Rubuwai dan Nurjannah dimana kepela madrasah sebagai desainer, evaluatur, manajer, administrator, leader, fasilitator, inovator, motivator dan sebagai liasion atau penghubung dengan dunia luar. ${ }^{63}$

\section{4) Pembahasan}

Dari hasil analisis jurnal-jurnal tentang kepemimpinan transfirmatif dan pola kepemimpinan kepala sekolah dapat ditarik kesimpulan diantaranya perubahan dan perkembangan zaman membutuhkan seorang pemimpin yang

\footnotetext{
59 Syarafudin, "Pola Kepemimpinan Kepala Sekolah dan ompetensi Guru dalam Pengelolaan Pembelajaran di Sekolah Menengah”, ... 129.

${ }^{60}$ Lusila Parida, Sirilus Sirhi dan Danie Dike, “Pola Kemepmimpinan Kepala Sekolah dalam Penguatan Karakter di Sekoah Dasar Kota Sinntang-Kalimantan Barat”, Jurnal Profesi Pendidikan Dasar. 6. No. 2 (Desember 2019): 160. Didik",...70

61 Ujang Wahyudin,, "Pola Kepemimpinan Kepala Sekolah dalam Membangun Akhlak Peserta

62 I Made Sila dan Ida Bagus Rai, "Pengaruh Pola Kepemimpinan Kepala Sekolah dalam Mengatas Penyalah Gunaan Narkoba Pada Siswa di Sekolah Menengah Atas Dwijendra Denpasar”,...11.

${ }^{63}$ Ismail Suardi Wekke, Efa Rubuwati, dan Siti Nurjannah, "Kepemimpinan Transformatif di Madrasah Minoritas Muslim Papua Barat”,... 3-4.
} 
peka dan mampu mengatasi semua tantangan yang ada serta selalu beradaptasi dengan perubahan yang terjadi. Oleh karena itu, dibutuhkan pemimpin yang mampu merubah dan mempengaruhi bawahannya maka dapat diterapkan model kepemimpinan transformatif. Seorang pemimpin yang menerapkan model kepemimpinan transformatif mampu mengubah situasi dan kondisi, memiliki kreatifitas, memiliki misi yang baik, memiliki pedoman nilai kebebasan, kesamaan, dan keadilan. Tidak hanya itu, pemimpin transformasional akan membuat bawahan melihat jika tujuan yang ingin dicapai lebih dari sekedar kepentingan pribadinya.

Lembaga pendidikan dalam meningkatkan kualitas dan kuantitas pendidikan membutuhkan seorang pemimpin yang mampu menyesuaikan dengan perubahan dan perkembangan jaman. Kepala madrasah sebagai pemegang kebijakan, pembaharuan pola kepemimpinan dan mempengaruhi tingkah laku pengikutnys dengan strategi yang dtetapkan. Kepemimpinan transformatif kepala madrasah memiliki motivasi dan semangat yang tinggi untuk mencapai tujuan lembaganya. Dari model kepemimpinan transformatif menurut Ownes memberikan gambaran bahwa seorang pemimpin yang menggunakan model transformatif mampu membangun kepercayaan bawahan, dan mempertinggi peluang keberhasilan yang subyektif. dilain sisi pemimpin juga mengangkat kebutuhan bawahan ke tingkatan yang lebih tinggi pada hierarki motivasi, kebutuhan bawahan diperluas, dan mentransformasikan perhatian mengenai kebutuhan bawahan serta pemimpin mempertinggi nilai kebenaran bawahan. Jadi ketika pemimpin mampu mempertinggi peluang keberhasilan yang subyektif dan mempertinggi nilai kebenaran bawahan serta menyesuaikan dengan harapan bawahan dan kondisi sekarang agar bawahan dapat melaksanakan kinerja sesuai dengan harapan. Ketika pemimpin memperhatikan hal-hal tersebut dan mempertinggi nilai bawahan agar dapat mencapai hasil atau tujuan dengan upaya tambahan maka bawahan akan memberikan kinerja yang lebih dari apa yang diharapkan.

Pola kepemimpinan di Madrasah Ibtidaiyah dengan model kepemimpinan transformatif yaitu kepala madrasah memotivasi dan semangat 
kepada guru dan tenaga pendidikan, memberikan dan menentukan solusi untuk masalah yang dihadapi oleh lembaga pendidikan, memberikan hal-hal positif kepada bawahannya, mencerminkan perilaku yang baik kepada bawahannya, dasar dalam menjalankan kepemimpinan di madrasah ibtidaiyah yaitu pada agama Islam, berbuat adil dalam segala hal, memiliki kharismatik, visi, agen perubahan, merangsang intelektual, empatik dan menumbuhkan kreativitas, menjadi panutan, menumbuhkan kreativitas dan inovasi, menerapkan 4I (Idealized Influence, Inspirational Motivation, Intellectual Stimulation, dan Individual Consideration), dan memiliki kepekaan terhadap perubahan dan perkembangan Ilmu Pengetahuan dan Teknologi.

Berdasarkan analsis mengenai jurnal-jurnal tentang model kepemimpinan transformatif dan pola kepemimpinan kepala madrasah. Penulis menemukan pola kepemimpinan kepala madrasah yang menggunakan model kepemimpinan transformatif.

Berikut ini pola kepemimpinan di madrasah ibtidiyah dengan model kepemimpinan transformatif:



Gambar 2. Pola Kepemimpinan di Madrasah Ibtidaiyah Dengan Model Kepemimpinan Transformatif 
Dengan menerapkan pola kepemimpinan di madrasah ibtidaiyah dengan model transformatif diharapkan kinerja guru dapat meningkat dan tenaga kependidikan. Kualitas dan kuantitas pendidikan meningkat di madrasah ibtidaiyah serta dapat menyesuaikan diri dengan perubahan dan perkembangan Ilmu Pengetahuan dan Teknologi. Pola kepemimpinan transformatif kepala sekolah di madrasah ibtidaiyah dapat membangun komunikasi yang baik dengan stakeholder sekolah, menjadi pengawas bagi bawahannya, menjadi pemimpin yang otoriter, selalui melibatkan guru dan tenaga kependidikan dalam mengambil keputusan, selalu memperhatikan guru dan tenaga kependidikan, memotivasi, memberi peghargaan, disiplin dan menjadi panutan bagi bawahannya. Pola kepemimpinan transformatif kepalas madrasah bertindak sebagai agen perubahan dan berperan dalam mengubah sistem pendidikan menjadi lebih baik atau katalisator.

Pada pola ini kepala madrasah diharapkan sebagai action planer yaitu mampu membuat program improvement yang belum pernah dilakukan untuk mengatasi masalah atau kelemahan dalam sistem yang sudah ada. sebagai inovator dimaksudkan kepala madrasah dapat melakukan pembaruan dengan sitem pendidikan yang sebelumnya sudah ditetapkan. Tidak hanya itu kepala madrasah juga sebagai motivator bagi bawahannya dan menjadi panutan dala melaksanakan pekerjaannya. Kepala madrasah juga diharapkan sebagai activator yaitu mampu bertindak cepat dan dapat merealisaikan sesuatu dengan maksimal baik dari ide sendiri, orang lain atau hasil musyawarah. Kepala sekolah menjadi goal planer yaitu memiliki tujuan dengan melaksanakan manajemen yang baik atau konsep untuk mencapai tujuan tersebut. Untuk memajukan sebuah madrasah kepala madrasah memiliki posisi sebagai penghubung dengan dunia luar serta menjalin komunikasi dengan pihak luar madrasah. Seorang kepala madrasah harus memiliki jiwa leader yang mampu memimpin, mengarahkan, mempengaruhi dan membimbing bawahannya untuk melaksanakan tugasnya dengan maksimal agar tujuan yang telah ditetapkan dapat terwujud. 


\section{Kesimpulan}

Hasil dari penelitian ini ditemukan bahwa pola kepemimpinan di Madrasah ibtidaiyah dengan model kepemimpinan transformatif dapat membantu kepala madrasah dalam menghadapi perubahan, perkembangan Ilmu Pengetahuan dan Teknologi, serta dapat menyesuaikan dengan kondisi lingkungan, dan mampu memutuskan kebijakan dengan cepat dan tepat. Pola kepemimpinan di madrasah dengan model kepemimpinan transformatif ini menjadikan seorang kepala madrasah sebagai seorang pemimpin yang memiliki kharismatik, mempunyai visi dan sebagai agen perubahan, dan mampu menyesuaikan dengan perkembangan zaman, katalisator, inovator, motivator, goal planer, aktivator, action planer, leader, panutan, motivator, perencana aksi, perencana tujuan, pemimpin serta penghubung. Kontribusi penelitian ini terhadap pendidikan di Indonesia adalah untuk menggambarkan pola kepemimpinan transformatif di Madrasah Ibtidaiyah (MI), sehingga diharapkan mampu mengubah pola kepemimpinan kepala madrasah yang masih tradisional menjadi pola kepemimpinan transformatif sehingga kepala madrasah diharapkan dapat menjadi agen perubahan dalam mengubah sistem pendidikan menjadi lebih baik. 


\section{DAFTAR PUSTAKA}

Aminuddin, M. Yusuf. "Model Kepemimpinan Transformatif (Kajian Kepemimpinn Transformatif di Lembaga Pendidikan Islam”. Al-Hikmah: Jurnal Studi Keislaman 7. No. 2, (2017): 14-33. doi: https://doi.org/10.36835/hjsk.v7i2.3280

Asmiyati. "Model Kepemimpinan Kepala Madrasah dalam Meningkatkan Mutu Sumber Daya di Madrasah Ibtidaiyah Ma'arif Giriliyo I Wukirasari Imogiri Bantul”. Jurnal Pendidikan Madrasah. 3. No. 1. (2018): 41-54. doi: https:doi.org/10.14421/jpm.2018.31-04

Assingkily. "Muhammad Shaleh. Karakteristik Kepemimpinan Transformasional di Madrasah Ibtidaiyah (MI) serta Relevansinya dengan Visi Pendidikan Abad 21. Jurnal Manajemen Pendidikan Islam. 4. No. 1, 150. (2019): 147168. doi: https://doi.org/10.144421/manageria.2019.41-09

Bustari, dkk. “Kepemimpinan Transformatif dalam Lembaga Pendidikan Islam”. Produ: Prokurasi Edukasi Jurnal Manajemen Pendidikan Islam. 1. No. 2. (2020).

Fatonah, Isti. “Kepemimpinan Pendidikan”. Jurnal Tarbawiyah. Vol. 10. No. 2. (2013): 109-125.

Hamzah, Amir. Metode Penelitian \& Pengembangan (Research \& Development) Uji Produk Kuantitatif dan Kualitatif Proses dan Hasil Dilengkapi Contoh Proposal Pengembangan Desain Uji Kualitatif dan Kuantitatif. Malang: CV. Literasi Nusantara, 2019.

Indarti, Luluk. "Dimensi-dimensi Kepemimpinan Transformatif Pendidikan Islam”. Ta'allum: Jurnal Pendidikan Islam. Vol. 05. No. 01. (2017). 2136. doi:https://doi.org/10.21274/taalum.2017.5.1.21-36

Kholiq, Abdul. “Model Kepemimpinan Transformatif Kepala Madrasah”. Jurnal Ilmiah Studi Islam. 17. No. 1. (Desember 2017). 34-52.

Komsiyah, Indah. "Kepemimpinnan Transformatif Perkembangan dan Implementasinya Pada Lembaga Pendidikan”. Ta'allum. Vol. 04. No. 02. (2016). 293-316. doi:https://doi.org/10.21274/taalum.2016.4.2.293-316.

Kuswaeri, Iwan. “Kepemimpinan Transformasional Kepala Sekolah”. Tarbawi. 2. No. 02. (Juli-Desember 2016).

Nadira, Dira. "Pola Kepemimpinan Kepala Sekoah di Yayasan Pendidikan Islam Amir Hamzah”. Jurnal Benchmarking: Jurnal Manajemen Pendidikan 
Islam. 1. No. 1. (2017).

Nurlena. “Tugas dan Fungsi Kepemimpinan Kepala Madrasah di Madrasah Ibtidaiyah”. Jurnal Pendidikan Islam. 4. No. 1. (2020). 24-32.

Parida, Lusila, Sirilus Sirhi dan Danie Dike. "Pola Kemepmimpinan Kepala Sekolah dalam Penguatan Karakter di Sekoah Dasar Kota SinntangKalimantan Barat”. Jurnal Profesi Pendidikan Dasar. 6. No. 2. (Desember 2019). 145-164.

Rahmawati, Wasik Fajar. "Pola Kepemimpinan Kepala Sekolah Terhadap Kinerja Guru”. Skripsi. Program Studi Pendidikan Anak Usia Dini, Fakultas Keguruan dan Ilmu Pendidikan, Universitas Muhammadiyah Surakarta. (2020)

Rofik, Chaerul. "Kepemimpinan Transformasional dalam Lembaga Pendidikan Madrasah”. Jurnal Penelitian Agama. 20. No. 2. (Juli-Desember 2019). 203-226.

Septaningrum, Noor. Pola Kepemimpinan Kepala Sekolah di SDIT Cahaya Bangsa Mijen Semarang. Skripsi. Fakultas Ilmu Tarbiyah dan Keguruan Universitas Islam Negeri Walisongo Semarang. (2015).

Sila, I Made dan Ida Bagus Rai. "Pengaruh Pola Kepemimpinan Kepala Sekolah dalam Mengatas Penyalah Gunaan Narkoba Pada Siswa di Sekolah Menengah Atas Dwijendra Denpasar”. Widya Accarya. 9. No. 2. (2018). 3. doi: https://doi.org/10.46650/wa.9.2.640.\%25p

Sudharto. "Pengaruh Pola Kepemimpinan Kepala Sekolah dan Suasana Kerja Terhadap Kinerja Guru”. JMP. 1. No.2. (Agustus 2012). doi:https://doi/org/10.26877/jjmp.v1i2.308

Sugiyono, Metode Penelitian dan Pengembangan (Research and Development/ R\&D). Bandung: Alvabeta. 2019.

Sukino, Arief. "Kepemimpinan Transformatif dalam Pengembangan Manajemen Madrasah Beroriaentasi Mutu. An-Nidzam”. 03. No. 01. (2016): 81-100.

Suminto. “Karakteristik Kepemimpinan Transformatif,” Pedagogy . 4. No. 1. (2017): 1-9.

Syafnan. “Kepemimpinan Transformatif di Lembaga Pendidikan”. Jurnal Ta'dib. 13. No. 1. (2010). doi:https://dx.doi.org/10.31958/jt.v13i1.177.

Syarafudin. "Pola Kepemimpinan Kepala Sekolah dan Kompetensi Guru dalam Pengelolaan Pembelajaran di Sekolah Menengah”. Jurnal Ilmiah Profesi 


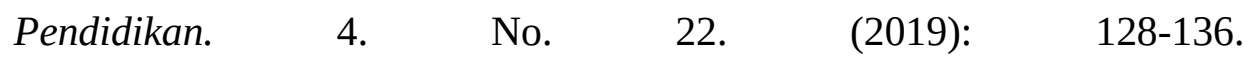
doi:https://doi.org/10.29303/jipp.v4i2.94

Wahyudin, Ujang, "Pola Kepemimpinan Kepala Sekolah dalam Membangun Akhlak Peserta didik. Jurnal Tawazun”. 11. No. 1. (Januari-Juni. 2018). 52-73. doi:http://dx.do.org/10.2832/tawazun.v1i1.1659

Wekke, Ismail Suardi, Efa Rubuwati dan Siti Nurjannah. "Kepemimpinan Transformatif di Madrasah Minoritas Muslim Papua Barat”. J_MPI (Jurnal Manajemen Pendidikan Islam). 2. No. 1. (2017): 1-10. doi: https://doi.org/10.18860/jmpi.v2i1.4354 
